\title{
Discourse metaphors: The link between figurative language and habitual analogies
}

JÖRG ZINKEN*

Abstract

Cognitive linguists have long been interested in analogies people habitually use in thinking and speaking, but little is known about the nature of the relationship between verbal behaviour and such analogical schemas. This article proposes that discourse metaphors are an important link between the two. Discourse metaphors are verbal expressions containing a construction that evokes an analogy negotiated in the discourse community. Results of an analysis of metaphors in a corpus of newspaper texts support the prediction that regular analogies are form-specific, i.e., bound to particular lexical items. Implications of these results for assumptions about the generality of habitual analogies are discussed.

Keywords: discourse metaphor; metaphor theory; figurative meaning; corpus linguistics.

\section{Introduction}

Analogies play a fundamental role in some of the most impressive capabilities of the human mind. The detection of analogies is a driving force in the development and acquisition of relational concepts (Gentner 2003), and figurative analogies help us to agree or disagree on relatively intangible topics, from temporal relations (Boroditsky 2000; Evans 2004) to international politics (Musolff 2004; Zinken 2003). Much research in cognitive linguistics has described possible analogies underlying figurative talk about such intangible topics (Lakoff and Johnson 1999, 1980; e.g., Clausner and Croft 1997; Grady 1999). ${ }^{1}$ However, the nature of the relationship between language use and analogical schemas remains unclear. Let us assume we read in a newspaper article of a nation-state that is 
described as a house built by many generations, with a fundament of stable values and open doors for newcomers. Do we construct a state-house analogy to make figurative sense of this utterance? This might suggest that the particular lexical items used in an utterance are a factor in the development of habitual analogical schemas. Or is this figurative usage understood as an instance of a more general institution-building analogy that has been abstracted from countless instances of talking about different types of institutions in terms of different types of buildings (as might be suggested on the basis of Lakoff 1993)? This would suggest that habitual analogical schemas are the result of the members of a language community making the same abstraction over the utterances they encounter. Or maybe language just expresses very general analogies that are formed independently of language itself - maybe it is a preconceptual intuition of equating organisation with physical structure that leads us to talk about a nation-state as a house (as might be suggested on the basis of Grady and Johnson 2003; see also Lakoff and Johnson 1999)? This would suggest that habitual analogical schemas are a natural epiphenomenon of human ontogenesis (as proposed most explicitly in the new afterword to Lakoff and Johnson 2003).

Cognitive linguistic approaches to metaphor have repeatedly been criticised for being too vague with regard to the link they assume to hold between analogical schemas and language use (Murphy 1996; Jackendoff and Aaron 1991; Vervaeke and Kennedy 1995; Stern 2000). Being explicit about the link one assumes between behavioural data and theoretical constructs is essential for a falsifiable account of semantic schematization in general, and figurative language and thought in particular. In the present paper, a possible link is proposed and evidence in its support sought. The proposal follows the first of the three possibilities broadly outlined above: that the particular vehicles used in active metaphors (Goatly 1997; Goddard 2004) are the driving force in the negotiation of habitual analogies.

Section two provides some conceptual groundwork. This involves a brief description of the approach to figurative language that the present study is based on, and an introduction to the construct of discourse metaphors, the crucial nexus between language use and habitual analogies. Section three reports a corpus analysis of discourse metaphors, which assesses the prediction that repeatedly evidenced metaphorical meanings are form-specific, i.e., that the particular lexical items used in discourse are associated with particular figurative usages. In section four, the present approach will be discussed in the context of alternative views of figurative language in cognitive linguistics, and section five presents some conclusions. 


\section{Figurative language in creative and conventional meaning construction}

\subsection{The lexical concepts and cognitive models approach to figurative language}

The lexical concepts and cognitive models approach to figurative language is concerned with the functions of the semantic structure associated with particular constructions in figurative meaning construction (Evans and Zinken forthcoming). The approach makes a distinction between two types of knowledge structure involved in linguistic meaning construction: lexical concepts and cognitive models. Lexical concepts are language-specific, protean representations, governed by conventions. Lexical concepts are part of all linguistic constructions, from morphemes to syntactic constructions. They do not encode the meaning of a word (or morpheme, or syntactic construction). Rather, they can be thought of as instructions to access a particular area of encyclopaedic knowledge.

These bodies of encyclopaedic knowledge are broadly termed cognitive models, but they should not be thought of as representations written in a symbolic code, as a symbolic 'language of thought' (Fodor 1975). Rather, encyclopaedic knowledge might be represented in the 'language' of the specific modality in which the experience was made (Barsalou 1999) visual, auditory, or, indeed verbal, for example in cases of learning through verbal instruction.

Linguistic forms provide prompts for meaning construction (Evans 2006). When an utterance feels conventional, this means that a meaning that is relevant in the current context was constructed rapidly and seemingly effortlessly. When an utterance feels figurative, this means that the construction of a relevant meaning required the listener to access knowledge that is, in the given context, not directly accessed by the vehicle. The more work has to be invested in construing a relevant meaning, the more figurative the utterance is bound to feel. ${ }^{2}$ The difference can be illustrated with the utterances "this thing is a bulldozer" and "Robert is a bulldozer" (discussed in Carston 2002; see also Gibbs and Tendahl 2006). Both utterances involve the syntactic construction " $\mathrm{x}$ is a $\mathrm{y}$ ", associated with a lexical concept that we can call CLASS INCLUSION and that we know invites us to put $\mathrm{x}$ into the category of $\mathrm{y}$, together with other, similar representatives of the category. The lexical concept associated with the deictic NP "this thing", maybe accompanied by a pointing gesture or a head nod, immediately guides us to attend to the relevant object which must be given in the discourse context - e.g., it might guide us to look at a particular vehicle. The lexical concept associated with the form "bulldozer" makes our knowledge of a certain type of work vehicle directly 
accessible - knowledge that might for most speakers of English be restricted to visual experience.

The utterance "Robert is a bulldozer" cannot be understood in this straightforward manner, because the syntactic invitation to include Robert, a person, into the category of bulldozers leads to a contradiction. Let us assume that this utterance is made in the context of discussing Robert's interpersonal qualities. The knowledge required to perform a class-inclusion with bulldozers as the class in question, which for many speakers presumably involves the vague knowledge that bulldozers are a type of machine used in certain work contexts, will not be useful for meaning construction in such a context. So we explore the vehicle further, and maybe mentally simulate the flattening effect that the motion of a bulldozer has on the earth it drives over. The simulation of physical 'flattening' might, in the given context, evoke the force dynamics that conventionally inhere in the way speakers of English talk about interpersonal relations involving 'pressure', 'persuading', or 'urging' (Talmy 2000). Once structures in the two domains - say, the domain of bulldozing and the domain of bullying - are matched, the analogy is established and bulldozingimagery can be used to elaborate on Robert's social behaviour.

Lexical concepts place an order on the accessibility of encyclopaedic knowledge, an order which is usage-driven. Encyclopaedic knowledge that is frequently relevant in the usage of a particular construction becomes more accessible. This leads to a situation where different kinds of knowledge can be immediately accessible through one particular lexical item in appropriate contexts, i.e., to polysemy. Consider the alternative, though equally unfavourable, assessment of Robert's interpersonal qualities: "Robert has no warmth". While this utterance could just about conceivably be intended in a reading referring to temperature - in the context of talk about Robert's corpse maybe - in a context of talk about personality, the form "warmth" will be directly understood as referring to Robert's lack of empathy and engagement with others. In such a case, the process of meaning construction does not involve the matching of structures across domains and the construction of an analogy. The repeated use of warmth in the context of social relations has lead to the entrenchment of a separate lexical concept [warmth*], which directly provides access to knowledge of the relevant affective experience. ${ }^{3}$ At this point, what is required for meaning construction is the selection of the contextually appropriate lexical concept (Evans and Zinken forthcoming; see also Giora 1999). In other words, the process of meaning construction becomes one of 'vertical' class-inclusion (including Robert in the class of people with no warmth') and ceases to be one of 'horizontal' analogy (Bowdle and Gentner 2005). Whether such conventionalised usages should 
be termed metaphor is a matter of definition (Cameron 1999; Gentner et al. 2001; Glucksberg 2003).

\subsection{Discourse metaphors and regular analogies}

Schemas used regularly for analogical reasoning have been studied on the basis of naturally-occurring verbal behaviour in cognitive-linguistic discourse analysis (Musolff 2004; Chilton 1996; Zinken et al. forthcoming). For example, debates of European Union expansions are framed by house- and journey-metaphors (Musolff 2000; Bolotova and Zinken 2004), debates of international political relations frequently use marriagemetaphors (Musolff 2004), and debates on scientific achievements are often framed by race-metaphors (Nerlich 2006).

Analogies in public discourse use stereotypical representations of everyday situations to provide evaluative perspectives on contested topics (Musolff 2006). However, the figurative meaning of such schemas is not obvious. While the speaker proposing a particular metaphor has a specific figurative meaning in mind, new metaphors are initially open to several interpretations, and can be used for opposing evaluations (Hellsten 2000). This openness of analogical schemas leads to a period of negotiation, in which discourse participants aim to establish a 'conceptual pact' (Brennan and Clark 1996) regarding the meaning of the expression by repeating, reformulating, or rejecting the metaphor. A well-documented example is the history of the metaphor of the "common European House", brought into European public discourses by Mikhail Gorbachev in the mid-1980s (Chilton and Ilyin 1993; Zinken 2002; Zybatow 1995). While Gorbachev intended to convey a sense of the common responsibility of the states of Europe for the "common house", Western journalists picking up the phrase mainly thought about the freedom of moving from room to room that is possible within a family house. In other words, Gorbachev had intended to highlight the need for a common security policy by alluding to the stereotypical knowledge relating to the structure and stability of a house. The preferred interpretation of the metaphor in Western media, on the other hand, used the stereotypical knowledge of the social life of a family home as an analogue for post-cold-war relations in Europe (Chilton and Ilyin 1993).

Importantly in the current context, differences in the knowledge conventionally accessed by speakers when using the lexical item house (or the Russian dom) have led to diverging figurative interpretations. The experience of detached family houses and the accompanying positive evaluations are relatively prominent in the associations that Western Europeans have with houses. For speakers of Russian, on the other hand, the mental image of apartment blocks is relatively salient in 
associations with the lexical item dom (Chilton and Ilyin 1993). The same phenomenon should in principle exist within a language community: each speaker has some idiosyncratic associations with the word house, although we would expect a set of shared associations to say that somebody knows the meaning of the word (see Wierzbicka 1985). The development of a novel metaphor into a habitually constructed analogical schema therefore involves the repeated use of a particular form as the vehicle, and the accompanying negotiation of a shared figurative interpretation.

Constructions that are commonly used as metaphor vehicles to express a particular, negotiated analogical meaning will be termed discourse metaphors (Zinken et al. forthcoming). Discourse metaphors therefore constitute an intermediate stage in the life course of a successful figurative expression-from an innovative analogy to a conventional lexical concept. The difference between a discourse metaphor and a creative metaphor is that the analogy evoked by a discourse metaphor is part of the primary cognitive model profile directly accessed by the given lexical concept in the appropriate context (Evans and Zinken forthc.). While in the case of creative metaphors, encyclopaedic knowledge has to be 'searched' for the hearer to construct a relevant meaning, the relevant analogical schema is easily recalled in the case of discourse metaphors. This means that the process of meaning construction becomes more similar to conventional meaning construction. When the lexical item house is modified by the adjective European, the analogical schema of different countries living together like the members of a family in its home is directly constructed in a discourse where this is the negotiated interpretation. Still, the conventionalisation has not reached the point where EUROPEAN COMMUNITY would be a conventional lexical concept associated with the lexical item house, independent of the lexical concept HOUSE. The often clichéd feel of discourse metaphors comes from the fact that, on the one hand, the intended interpretation is readily available in the appropriate context but, on the other hand, the utterance still feels figurative because this interpretation is achieved using a form that in most contexts has a different referent.

In sum, a discourse metaphor is a linguistic expression containing a construction that, in the appropriate context, prompts the speaker/hearer to construct an analogical meaning that has been negotiated in the discourse. This means that discourse metaphors are form-specific in the sense that the analogy is evoked by a particular linguistic unit, i.e., a particular conventional form-meaning pairing. ${ }^{4}$ The discourse in question can vary in scope from a few speakers discussing a particular topic to all speakers communicating with mutually comprehensible utterances in a language community. 
This view of the development of analogical schemas predicts that discourse metaphors are form-specific, i.e., bound to particular linguistic constructions. This follows because the common ground for the negotiation of a figurative interpretation is the stereotypical encyclopaedic knowledge accessed by conventional lexical concepts associated with the form of the vehicle. We should therefore expect that extended meanings are motivated by the particular conventions associated with a lexical item. The assumption that discourse metaphors are form-specific leads to the prediction that different lexical items with similar or overlapping conventional usages, which belong to the same superordinate category, function differently as metaphor vehicles. This prediction is assessed in the following section.

\section{Are discourse metaphors form-specific?}

The aim of the study reported in this section was to see whether corpus data support the prediction that discourse metaphors are form-specific. It is predicted that lexical items that have similar and overlapping conventional usages function differently as vehicles of discourse metaphors. Alternatively, it could be that the relevant meanings used in figurative verbal behaviour are independent of particular linguistic constructions, but instead tied to superordinate categories, and that therefore lexical items that are conventionally used in the same contexts take on the same figurative functions in active metaphorical contexts in discourse.

It is an open empirical question how frequently a lexical item must have been used with the same figurative meaning in order for it to become a discourse metaphor. For the purposes of this article, the minimal criterion will be that a lexical item must have been used at least twice in the corpus with the same figurative meaning to have the potential of being a discourse metaphor. This generous criterion has been chosen because of the limited size of the available corpus.

\subsection{Method}

Corpus. More than 8,000 metaphors were annotated in a sub-sample of the Wende-corpus of the Institute for German Language in Mannheim, Germany (see Baranov and Zinken 2003), which comprises approximately 3.3 million words. It contains newspaper texts and, to a lesser extent, politicians' speeches from mid-1989 to the end of 1990 relating to the end of state socialism in Eastern Germany and Eastern Europe.

Procedure. Annotation proceeded in a corpus-driven manner (McEnery et al. 2006). Texts were read in their entirety, and each identified 
metaphor was annotated using a set of meta-language descriptors (see Baranov 2006, for details). Data-collection continued until 8,000 metaphors were annotated.

Only active metaphors were annotated. Metaphors were considered active when an understanding of the utterance required meta-lexical awareness (Goddard 2004), when the author made use of an interference between lexical concepts (as when someone would refer to Robert as a "tropically warm" person, leading to an interference between the two conventional lexical concepts, the temperature-related WARMTH made salient by the adverb, and the emotion-related WARMTH* made salient by the context), or when the figurativity of the expression was highlighted with the use of "tuning devices" (Cameron and Deignan 2003) such as inverted commas or phrases such as "so to speak". Discussions between coders were used in the first phase of annotation to resolve unclear cases.

Four broad vehicle categories, building, container, path, and transport, were chosen for analysis. Only nominal metaphors were included. This produced 36 metaphor vehicles. The 36 lexical items were identified to be used metaphorically 266 times in the corpus (cf. Appendix). In order to increase the comparability of lexical items, they were attributed to levels of categorisation. Two independent coders classified each of the 36 lexical items as being at the superordinate, the basic, or the subordinate level. Coders were provided with brief definitions of each level that were formulated on the basis of Rosch et al. (1976) and asked to make quick, intuitive decisions. Cohen's kappa showed good agreement, $K=.82$. A third coder rated all 36 items, and this coder's judgements were used to resolve disagreements between the first two coders. Five lexical items from the four categories were judged to belong to a superordinate level of categorisation, 22 to the basic level, and nine to a subordinate level. This bias towards the basic level was expected, since the basic level is the default level for reference (Glucksberg 2001). The analysis was further restricted to lexical items from the basic level.

Lexical items were used metaphorically with very different frequency, both in absolute and in relative terms. The two most frequently used vehicles were Weg 'path' (118 occurrences), and Haus 'house' (53 occurrences). Each of the remaining 34 vehicles was annotated less than 10 times. Some lexical items were relatively rarely used with metaphorical functions, others relatively frequently (see Appendix). However, these numbers need to be treated with caution because of the procedure of annotation. We know that the lexical item Ruine ("ruin") occurs 51 times in the whole corpus, and that at least seven of these occurrences are metaphorical. However, it could be that more than seven occurrences are metaphorical. The same applies to the other lexical items. 
Vehicle-pairs which were similar in their conventional meanings recorded in dictionaries were selected for comparison. The selected vehicle pairs were: path - course; bastion - fortress; kettle - pot; and boat-ship. Figurative meanings that were expressed at least twice with the same vehicle were considered to have the potential of being a discourse metaphor.

Materials. Two dictionaries were used to compare the figurative functions of conventionally similar lexical items. These were the electronic versions of the digital lexicon of the German language in the 20th century (Das digitale Wörterbuch der deutschen Sprache des 20.Jahrhunderts, referred to as digital lexicon in the following), and the Bertelsmann lexicon (Bertelsmann Wörterbuch, referred to as Bertelsmann lexicon in the following).

\subsection{Results}

The aim of the analysis was to find out whether lexical concepts belonging to the same superordinate category were used with the same or with different metaphorical functions.

Path-Course. The conventional meanings of Weg 'path' and Bahn 'lane/course' overlap. Both can refer to paths that have developed in an unplanned manner through the activity of walking, or as the result of intentional construction to enable the reaching of a goal. The meaning of Weg is explained using the term Bahn, and vice versa, in the digital lexicon. There are also differences in the conventional uses of the two lexical items. The Bertelsmann lexicon emphasises that the word Bahn also refers to a pre-determined trajectory of motion, e.g., of planets. The lexeme Weg, but not Bahn, also refers to the distance that must be crossed to reach a goal. Furthermore, Weg is conventionally used to refer to the manner of executing an action, similar to the English "a way to solve the problem", and to the goal-directedness of actions ("the path to freedom"). A further conventional usage of Bahn is to express the idea of restrictions: "in geregelten Bahnen handeln" (literally 'to act in regulated courses', meaning 'acting within certain boundaries').

The word Weg 'path' is frequently used in the corpus in its conventional meanings of MANNER OF ACTION and GOAL-DIRECTEDNESS OF ACTION to discuss varied political activities. Active metaphors using the vehicle Weg 'path' $(N=118)$ exploit the interference between 'Weg [goal-directedness]' and the lexical concept with the more 'concrete', i.e., intersubjectively available, referent 'Weg [path]' to construct an analogy in which a particular political activity or task is presented as a path that 
has to be traversed. The topics of such metaphors are varied, but one political task that is repeatedly talked about as a path to be travelled is the unification of the two German states.

(1) $[\ldots]$ wir haben nie versucht, irgendwelche Stolpersteine in den Weg der deutschen Einigung zu legen.

'We have never tried to put any stumbling blocks into the path of German unity'

(Berliner Zeitung, October 8, 1990)

(2) $[\ldots]$ der Weg zur deutschen Einheit ist mit praktischen Problemen gepflastert.

'The path to German unity is paved with practical problems'

(Rheinischer Merkur, April 20, 1990)

These figurative usages of $\mathrm{Weg}$ 'path' emphasise the effort required to reach a political goal.

The word Bahn 'course' is frequently used in public discourse to express its conventional meaning of restrictions and regulations. Metaphors using the vehicle Bahn 'course' $(N=6)$ exploit the interference between the lexical concepts 'Bahn [regulation]' and 'Bahn [trajectory]' to present a development analogically as an object following a trajectory. All metaphorical usages of Bahn in the current corpus express this figurative meaning. However, none of the metaphor topics is expressed more than once, so that Bahn should not be considered a discourse metaphor of the Wende-discourse. In example (3), a career is conceptualised as an object following a pre-given course:

(3) Unter Führung der SED sei die DDR dank der schöpferischen Arbeit des ganzen Volkes von Jahr zu Jahr als ein stabiler Eckpfeiler des Sozialismus und des Friedens, als reale Alternative zum Kapitalismus erstarkt. Der Weg habe natürlich nicht immer über glatte Bahnen geführt.

'Under the leadership of the SED, the GDR had gathered strength, thanks to the creative work of the entire people, as a stable pillar of socialism and peace, as a real alternative to capitalism. Of course, this path had not always led along a smooth course'.

(Berliner Zeitung, October 6, 1989)

Not a single figurative usage of the lexeme Weg 'path' uses this vehicle to express the figurative meaning expressed with Bahn 'course', that of a pre-given trajectory, or vice versa. In conclusion, then, we can say that although the lexical items $\mathrm{Weg}$ and Bahn overlap in their contexts of conventional usage, they do not overlap in their figurative functions. 
Bastion-Fortress. The lexical items Bastion 'bastion' and Festung 'fortress' are similar in their conventional meanings. Both refer to military fortifications. They differ in that bastions were parts of a fortress, built on its outskirts. Bastions became important with the invention of guns as an outer post for defence.

The lexeme Bastion 'bastion' is used as a metaphor vehicle $(\mathrm{N}=2)$ exclusively to refer to elements of the state-socialism of the GDR - to the state as a whole in one case, to the Berlin wall in the other. This association of the GDR with a bastion was well established in the official public GDR language, which had branded the GDR, somewhat paradoxically, as a Bastion des Friedens 'bastion of peace'. The active metaphorical usages in the Wende-corpus, however, clearly play on the original battlefunction of bastions. They are used to express the antagonism between the state-socialist Eastern Europe and the capitalist Western Europe:

(4) Partei und Regierung der DDR wüßten, daß sie auf einer "vorgeschobenen Bastion des Sozialismus" stünden.

"Party and government knew that they were standing on an "outer bastion of socialism"'.

(Frankfurter Allgemeine Zeitung, 14/08/1989)

Knowledge of the original function and structure of medieval bastions is likely to vary considerably across speakers of German. The minimum knowledge required to make figurative sense of (4) might be merely that bastions had a function in military conflicts between two parties. Of course, such an assumption about bastions is strongly suggested by the metaphor's topic itself - the conflict between socialism and capitalism.

Metaphors using the vehicle Festung 'fortress' $(\mathrm{N}=2)$, on the other hand, are variable in the topics they take. The topics of the two usages in the corpus are Europe and legislation respectively. The metaphor of the European fortress expresses the impossibility for aspiring new members to enter into the European Union. The metaphor of a particular piece of legislation as a fortress expresses the (contested) immutability of that legislation:

(5) $[\ldots]$ aber die Väter und Mütter unserer Verfassung [...] haben beispielsweise die 5-\%-Klausel nie als eine Festung begriffen, die nicht eingenommen werden kann.

'but the fathers and mothers of our constitution have never understood the $5 \%$ stipulation as a fortress that cannot be captured'.

(Berliner Tagespost, 05/09/1989)

In both usages, it is the idea of the impenetrability of a fortress that is figuratively exploited, not, as in the case of the bastion-metaphors, its 
military use in an antagonism between two parties. Although the lexeme Festung 'fortress' is not part of a discourse metaphor in this corpus, because no topic is conceptualised twice using this vehicle, it is interesting to note that the same relational encyclopaedic knowledge - that of impenetrability - is relevant in both contexts in which the vehicle Festung 'fortress' is used. ${ }^{5}$

The knowledge that speakers of German have of bastions and fortresses is presumably much vaguer than the knowledge they have of paths and courses. Indeed, the figurative interpretations of both bastion- and fortress-metaphors strongly rely on their topical context, as emphasised by interaction theories of metaphor (Black 1993 [1979]). The lexical concept used as a vehicle clearly plays an important part in this interaction: as with path- and course-metaphors, the vehicle fortress is never used to express the figurative meaning expressed with bastion, and vice versa.

Kettle - Pot. The lexical items Kessel 'kettle' and Topf 'pot' are very similar in their conventional meanings. Both refer to common household objects that are used in the preparation of meals. The digital lexicon describes both as predominantly large containers used for cooking. One difference is that as a household object, kettles are used exclusively as a kitchen tool - the heating of fluids is explicitly mentioned as a function in the digital lexicon and the Bertelsmann lexicon-whereas pots serve various functions, including, e.g., the storage of food and the planting of flowers. Beyond the household, a different kind of Kessel 'kettle' was used in steam engine locomotives.

Metaphors using the vehicle Kessel 'kettle' $(\mathrm{N}=6)$ regularly express the special situation in the GDR in late 1989: The so-called Monday demonstrations were increasingly putting 'pressure' on the GDR government to relax the restrictions on travelling abroad that existed for GDR citizens. Releasing the 'pressure' by allowing people to leave the GDR bore the danger of a mass emigration; restoring the restrictions bore the danger that the 'kettle might explode', i.e., the danger of a revolution:

(6) [...] eine plötzliche Drosselung der großzügigen Genehmigung bei Westreisen und Ausreisen von DDR-Bürgern würde den Druck im Kessel der "Hinterbliebenen" schlagartig so sehr erhöhen, daß die SED-Führung sich erstmals vor einem neuen 17. Juni fürchten müßte.

'A sudden curb in the generous permissions for GDR-citizens to travel to the West or emigrate would abruptly heighten the pressure in the kettle of the ones left behind so much that the SED government would for the first time have to fear a new 17th June'.]

(Spiegel, September 18, 1989) 
(7) Schmidt über die Angst der SED: “der Druck muß unter dem Kessel bleiben. Die Führung drüben muß die Sorge haben, daß die DDR ausblutet. Nur dann bewegt sich wirklich etwas".

"Schmidt on the fear in the SED: "The pressure must remain on the kettle. The government over there must be afraid that the GDR bleeds to death. Only then things will move'.

(Bild, Novermber 11, 1989)

The kettle metaphor was a discourse metaphor in the Wende-discourse. The figurative meaning uses the idea of increasing pressure in a closed kettle that comes with increasing heat. The figurative use of this logic in a social context is aided by the analogical force dynamics of physical and social pressure (Talmy 2000). For example, the pressure dynamics of the steam engine are embodied in a variety of German idioms, such as jemandem Dampf machen ('to make steam for somebody', i.e., to put pressure on somebody) or Dampf ablassen ('to let off steam', i.e., to release (psychological) pressure). It is possible that the figurative usages of this vehicle, in the given context, remind readers of the steam engine dynamics conventionally embodied in idioms of interpersonal pressure. Alternatively, it is possible that readers construct a figurative meaning on the basis of their own experience with the steam pressures involved in cooking.

The vehicle Topf 'pot' $(\mathrm{N}=3)$, on the other hand, is used to criticise the lack of making important distinctions. The particular topics of the metaphor vary (including the discussion of company budgets, social groups, and regions within Germany), but the evaluation conveyed by this figurative expression is the same across contexts:

(8) Fünf Prozent wären im gesamtdeutschen Topf gerade ein Prozent wert.

'Five percent [in the GDR] would be worth all but one percent in the entire German pot'.

(Stern, August 2, 1990)

This usage of the pot metaphor is clearly inspired by the idiom verschiedene Sachen in einen Topf werfen ('to throw diverse things into one pot') which expresses exactly the same evaluation as the pot metaphors in the corpus. Figurative usages of the vehicle pot cannot be considered discourse metaphors, because they are not used repeatedly to conceptualise the same topic. Again, the lexical items kettle and pot, despite their overlapping conventional usage, are never used to express the same figurative meaning.

Boat-Ship. Finally, the lexical items Boot 'boat' and Schiff 'ship' are similar in their conventional meanings. Both refer to basic types of 
vehicles used to travel on water. Differences include the following: a boat is defined as a small vehicle, whereas a ship tends to be bigger according to both the digital and the Bertelsmann lexicon. A boat is also technologically relatively simple, using rows or a sail for locomotion. A ship is technologically more complex, and steering a ship requires expert knowledge. Metaphors using the vehicle Boot 'boat' $(N=7)$ express two figurative meanings more than once. The first of these is the idea of different people sharing a common interest in a particular situation:

(9) $[\ldots]$ aber wird dieses Gespenst nicht von der SED dazu benutzt, die Opposition ins Boot zu ziehen, um damit doch noch ans rettende Ufer gelangen zu können?

'but isn't this ghost being used by the SED to pull the opposition into the boat in order to be able to reach the safe bank after all?'

(Rheinischer Merkur, January 26, 1990)

This usage builds on the conventional meaning of the idiom 'im gleichen Boot sitzen' ('to be sitting in one boat'), which means to have a shared interest or to be in a dangerous situation together.

The other repeated usage of a boat metaphor refers to Germany as a boat - in which there is limited space for newcomers:

(10) $[\ldots]$ was bisher die Westdeutschen nur den aus aller Welt hereindrängenden Asylanten entgegengehalten haben, hören nun auch die Ankömmlinge aus der DDR: das Boot ist voll.

'people arriving from the GDR now get to hear what West Germans have so far only been telling asylum seekers coming from around the world: the boat is full'.

(Spiegel, August 14, 1989)

Reference to limited space on the German 'boat' is a common form of rationalising anti-immigrant sentiments in public discourses beyond the one under consideration. Metaphors using the vehicle Schiff 'ship' $(\mathrm{N}=4)$ are used for other purposes. This vehicle is used in various contexts, e.g. to conceptualise a complex economic project, by referring to it as a ship going through heavy water:

(11) $[\ldots]$ daß es bei der Beratung am Wochenende stürmisch zuging, ist dem Umstand geschuldet, daß die "Wirtschaftskapitäne" ihr Schiff durch rauhe See steuern müssen.

'The stormy atmosphere during the negotiations this weekend was due to the fact that the 'economy captains' have to steer their ship through a rough sea'.

(Neues Deutschland, December 11, 1989) 
This metaphor of economic development as a ship on a course might be a discourse metaphor of public economy-related discourse more generally, although it has not been found repeatedly in this corpus. The metaphor involves the knowledge that a ship is a complex system the steering of which requires expertise - an interpretation which is again made salient by the context.

3.2.3. Discussion. Lexical items with similar conventional meanings were systematically used to express different figurative meanings in the present corpus. This was true for active metaphors of varying frequency and discourse scope. The GDR-kettle analogy, which was repeatedly used only in a very specific discourse (the Wende-discourse in late 1989), was never expressed using conventionally similar vehicles, such as pot. Similarly, the unification-path analogy, which is used frequently in public discourse across topic domains, was never expressed using conventionally similar vehicles, such as course. No counterevidence to the qualitative observations reported here was found. That is, there was no occurrence of, e.g., a path metaphor expressing a figurative meaning that was expressed in another context with a course metaphor. This result supports the prediction that the conventional semantics of particular linguistic constructions are associated with particular figurative usages.

\section{General discussion}

Lexical items belonging, in their conventional function, to the same superordinate category differ systematically in their behaviour as metaphor vehicles. Even lexemes with very similar and overlapping conventional meanings do not overlap in their extended meanings in active metaphorical usage. These results support the prediction that form-specific lexical concepts are a factor in the development of habitual analogies.

How generalisable are these findings from newspaper discourse on post-communist transformation to the development of habitual analogies in general? Maybe only local and context-specific topics (such as the changing preoccupations of public discourse) are understood via the specific semantics of linguistic constructions, whereas more general topics are understood via general and more abstract representations. For example, some research suggests that time is an abstract domain which is understood through general motion schemas (Lakoff and Johnson 1999; Boroditsky 2000; Gentner et al. 2002). However, Evans' (2004) study of the lexeme time suggests that this might not be the case. For example, the deictic motion verbs come and go are used to express a moment-sense of time (the time has come to take some action). Verbs lexicalising the 
velocity of motion, on the other hand, are used to express a durationsense of time (time drags when you're bored). These expressions are now conventional and unlikely to be understood metaphorically (see Gentner et al. 2001). Nevertheless, the systematic differences in meaning expressed by different verbs of 'temporal motion' suggest that the semantic representations conventionally associated with linguistic constructions play a role in the figurative elaboration of concepts in general.

Earlier work on habitual analogies in cognitive linguistics has formulated these at a more general level. In particular, proponents of Conceptual Metaphor Theory have suggested that metaphors in language reflect quite general metaphorical schemas in concept structure:

(12) One tends not to find mappings like A LOVE RELATIONSHIP IS A CAR or A LOVE RELATIONSHIP IS A BOAT. Instead, one tends to find both basic level cases (e.g., both cars and boats), which indicates that the generalisation is one level higher, at the superordinate level of the vehicle. In the hundreds of cases of conventional mappings studied so far, this prediction has been borne out: it is superordinate categories that are used in mappings. (Lakoff 1993: 212)

How do the results of the current study relate to this assertion? The present analysis has shown that lexical items with overlapping conventional usage differ in their behaviour as metaphor vehicles. But would it maybe be possible to generalise over them anyway? Consider the vehicles kettle and pot. These vehicles are used to convey different figurative conceptualisations: that of social pressures in the case of kettle, that of an undivided community in the case of pot. Still, both vehicles conventionally refer to types of containers, and both are used in relation to a nation-state - so maybe we could hypothesise that people use an analogical schema A NATION-STATE IS A CONTAINER in the comprehension of these utterances? This would seem consistent with earlier formulations in Conceptual Metaphor Theory, such as the one in (12). However, assuming that the general mapping NATION-STATE-CONTAINER is psychologically real, we would still need to assume the psychological reality of the more specific analogies social dynamics in a state-steam pressure in a kettle and set of regions - undivided contained space in a pot. This follows because if the general mapping NATION-STATE-CONTAINER was the only psychologically real analogical schema, the systematic differences in the figurative meanings evoked by particular lexical concepts could not be explained. However, if we assume that a more specific analogical schema such as social dynamics in a state-steam pressure in a kettle is constructed online in the comprehension of the respective figurative utterances, it is unclear what exactly the function of the more general mapping 
NATION-STATE-CONTAINER would be. In other words, it cannot be decided on the grounds of verbal behaviour data whether such general mappings are a psychologically real additional layer of analogical schemas, or whether they are a post-hoc artefact of sorting utterances on the part of the researcher.

More recent formulations of Conceptual Metaphor Theory regard habitual analogies as not at all necessarily linked to language. Rather, such schemas ('primary metaphors') are assumed to naturally arise in prelinguistic, embodied experience. They might, but need not be expressed in language:

(13) When the embodied experiences in the world are universal, then the corresponding primary metaphors are universally acquired. $[\ldots]$ These conceptual universals contribute [my emphasis, JZ] to linguistic universals, for example, how time is expressed in languages around the world [...]. (Lakoff and Johnson 1999: 56-57)

On the one hand, leaving the relationship between verbal behaviour and assumed schemas unclear is problematic for a cognitive-linguistic theory of conceptualisation. On the other hand, it does seem plausible that figurative meaning construction is constrained by the embodiment of human cognition. Whether this embodiment takes the form of a set of 'primary metaphors' or not is another question that is not addressable using verbal behaviour data.

\section{Conclusions}

Some cognitive linguistic work on metaphor has established a rhetorical divide between scholars who treat metaphor as a matter of thought and scholars for whom metaphor is 'merely' a matter of language (see Lakoff and Johnson 1980). However, it is unclear what it would mean to say that metaphor is 'merely' a matter of language. Making meaning with verbal means necessarily involves thinking. The dissociation of language and conceptualisation has hindered the cognitive-linguistic study of figurative conceptualisation from studying the phenomenon in its full complexity. A look at other species shows that the use of analogy is the exception rather than the rule in animal cognition, and that in crucial ways it probably is a matter of language (Gentner 2003). Analogy predominantly makes use of relational knowledge (cf. Gentner et al. 2001; Kintsch 2001). Given the relative difficulty of relational thought, external forms (as material symbols, Clark 2006) might be a crucial scaffold for relational imagination.

Methodologically, we need an account of the link we assume between analogical (or other figurative) schemas and verbal behaviour, because 
only then can we start making falsifiable claims, and only then can the cognitive-linguistic study of figurative language enter fully into the debates of the cognitive sciences. The construct of discourse metaphors is an attempt to bridge the gap between habitual analogies and verbal behaviour.

Discourse metaphors occupy a middle ground in the life-course of a successful metaphor, from innovation to conventional conceptualisation. They exemplify the stage of conventionalisation at which the term 'conventional metaphor' is not an oxymoron.

Received 26 January 2006

University of Portsmouth, UK

Revision received 24 January 2007

\section{Appendix}

Table 1. Lexical-concepts used in the study (English gloss in parentheses). Items grouped by category and level of schematicity, and sorted by frequency. The first number refers to annotations of metaphorical usages, the second to overall frequency in the Wende-corpus.

\begin{tabular}{|c|c|c|c|}
\hline $\begin{array}{l}\text { Vehicle } \\
\text { category }\end{array}$ & Superordinate level & Basic level & Subordinate level \\
\hline building & $\begin{array}{l}\text { Gebäude } \\
\text { (building)(3/253) } \\
\text { Architektur } \\
\text { (architecture)(3/44) } \\
\text { Konstruktion } \\
\text { (construction)(1/23) }\end{array}$ & $\begin{array}{l}\text { Haus (house) }(53 / 1,790) \\
\text { Ruine (ruin) (7/51) } \\
\text { Trümmer (debris)(4/33) } \\
\text { Bastion (bastion) (2/10) } \\
\text { Festung (fortress) (2/10) } \\
\text { Gefängnis (prison) (2/109) } \\
\text { Mühle (mill) (1/10) } \\
\text { Stall (barn) (1/30) }\end{array}$ & $\begin{array}{l}\text { Zwingburg } \\
(\text { stronghold })(1 / 1)\end{array}$ \\
\hline path & Reise (journey) (2/268) & $\begin{array}{l}\text { Weg (path)(118/1,957) } \\
\text { Hindernis } \\
\text { (obstacle)(9/72) } \\
\text { Brücke (bridge)(7/99) } \\
\text { Bahn (course) (6/93) } \\
\text { Pfad (pathway)(3/7) }\end{array}$ & $\begin{array}{l}\text { Irrweg } \\
\text { (wrong path)(4/15) } \\
\text { Umweg } \\
\text { (detour)(2/38) }\end{array}$ \\
\hline container & Gefä $\beta$ (container) (1/2) & $\begin{array}{l}\text { Kessel (kettle)(6/12) } \\
\text { Faß (barrel) }(4 / 26) \\
\text { Topf (pot) }(3 / 38) \\
\text { Eimer (bucket)(1/3) } \\
\text { Flasche (bottle)(1/41) } \\
\text { Kiste (box)(1/22) }\end{array}$ & $\begin{array}{l}\text { Latrinenkübel } \\
\text { (latrine pot) (1/1) } \\
\text { Mülleimer } \\
\text { (dustbin) (1/6) } \\
\text { Pulle (bottle)(1/5) }\end{array}$ \\
\hline transport & & $\begin{array}{l}\text { Boot (boat) (7/36) } \\
\text { Schiff ( ship) (4/29) } \\
\text { Karren (cart) (1/12) }\end{array}$ & $\begin{array}{l}\text { Geisterschiff } \\
\text { (ghost-ship) (1/1) } \\
\text { Kahn (barge)(1/22) } \\
\text { U-Boot } \\
\text { (submarine)(1/2) }\end{array}$ \\
\hline
\end{tabular}




\section{Notes}

* I gratefully acknowledge detailed comments from Ewa D browska and two anonymous reviewers. I would further like to thank Mike Chase, Gitte Rasmussen Hougaard, Andreas Musolff, Katarzyna Micha owska-Zinken, and Jordan Zlatev for comments on earlier versions of this paper. Some of the proposals in this paper have benefited from discussions with Vyv Evans. Correspondence address: University of Portsmouth, Department of Psychology, King Henry I Street, Portsmouth PO1 2DY, UK. Tel.: +44 239284 6333. Fax: +44 239284 6300. Author's e-mail address: 〈joerg.zinken @port.ac.uk $>$.

1. Most cognitive linguistic research on figurative language talks about metaphor rather than analogy. I use both terms interchangeably in this article, treating the kind of metaphor I focus on as a subtype of analogy, see Gentner et al. (2001).

2. Consistently, psychophysiological evidence shows that a gradual rise in the figurative quality of an utterance leads to a gradual rise in mismatch negativity, which is associated with effort in meaning construction, see Coulson and Petten (2002).

3. The asterisk is conventionally used in relevance-theoretic literature to indicate an abstracted category, see Carston (2002).

4. The entrainment of figurative meanings might be form-specific in an even stronger sense: Deignan $(2005 ; 1999)$ presents corpus data which show that different derivates of the same linguistic unit express different figurative meanings.

5. The European fortress did become a discourse metaphor in the public discourse on European unification in the 1990s, see Bolotova and Zinken (2004).

\section{References}

Baranov, Anatolij

2006 Metasprache zur Beschreibung von Metaphern im öffentlichen Diskurs. In Zybatow, Lew (ed.), Kulturelle Vorstellungswelten in Metaphern. Metaphorische Stereotypen der deutschen und russischen Medien als Hypertext. Frankfurt: Peter Lang, 19-49.

Baranov, Anatolij, and Jörg Zinken

2003 Die Metaphernstructur des öffentlichen Diskurses in Russland und Deutschland: Perestrojka- und Wende-Periode. In Symanzik, B., G. Birkfellner and A. Sproede (eds.), Metapher, Bild und Figur. Hamburg: Verlag Dr. Kovac, 93-121.

Barsalou, Lawrence W.

1999 Perceptual Symbol Systems. Behavioral and Brain Sciences 22, 577-609.

Black, Max

1993 [1979] More about metaphor. In Ortony, A. (ed.), Metaphor and Thought. Cambridge: Cambridge University Press, 19-41.

Bolotova, Elena, and Jörg Zinken

2004 Das russische und das deutsche Europa: Bauwesen-Metaphorik im russischen und im deutschen Europa-Diskurs. In Bracic, S., D. Cuden, S. Podgorsek and V. Pogacnik (eds.), Linguistic Studies in the European Year of Languages: Proceedings of the 36th Linguistic Colloquium, Ljubljana 2001. Frankfurt: Peter Lang.

Boroditsky, Lera

2000 Metaphoric Structuring: Understanding time through spatial metaphors.

Cognition 75(1), 1-28. 
Bowdle, Brian F., and Dedre Gentner

2005 The career of metaphor. Psychological Review 112(1), 193-216.

Brennan, Susan E., and Herbert H. Clark

1996 Conceptual pacts and lexical choice in conversation. Journal of Experimen-

Cameron, Lynne tal Psychology: Learning, Memory, and Cognition 22(6), 1482-1493.

1999 Operationalising 'metaphor' for applied linguistic research. In Cameron, L. and G. Low (eds.), Researching and Applying Metaphor. Cambridge: Cambridge University Press.

Cameron, Lynne, and Alice Deignan

2003 Combining large and small corpora to investigate tuning devices around metaphor in spoken discourse. Metaphor and Symbol 18(3), 149-160.

Carston, Robyn

2002 Metaphor, ad hoc concepts and word meaning-more questions than answers. UCL Working Papers in Linguistics 14. Available at http:// www.phon.ucl.ac.uk/home/PUB/WPL/02papers/carston.pdf.

Chilton, Paul

1996 Security Metaphors: Cold War Discourse from Containment to Common European Home. Frankfurt: Peter Lang.

Chilton, Paul, and Mikhail Ilyin

1993 Metaphor in political discourse. The case of the 'Common European House'. Discourse and Society 4(1), 7-31.

Clark, Andy

$2006 \quad$ Material symbols. Philosophical Psychology 19(3), 1-17.

Clausner, T. C., and W. Croft

1997 Productivity and schematicity in metaphors. Cognitive Science 21(3), 247282.

Coulson, Seana, and Cyma van Petten

2002 Conceptual integration and metaphor: An event-related potential study.

Memory and Cognition 30(6), 958-968.

Deignan, Alice

1999 Corpus-based research into metaphor. In Cameron, L. and G. Low (eds.),

Researching and Applying Metaphor. Cambridge: Cambridge University Press, 177-199.

2005 Metaphor and Corpus Linguistics. Amsterdam/Philadelphia: John Benjamins.

Evans, Vyvyan

2004 The Structure of Time: Language, Meaning and Temporal Cognition. Amsterdam/Philadelphia: John Benjamins.

2006 Lexical concepts, cognitive models and meaning-construction. Cognitive Linguistics 17(4), 491-534.

Evans, Vyvyan, and Jörg Zinken

forthc. Figurative language in a cognitive theory of meaning construction. In

Makris, C., R. Chrisley, R. Clowes and M. Boden (eds.), Art, Body and Embodiment. Cambridge: Cambridge Scholars Press.

Fodor, Jerry

1975 The Language of Thought. New York: Crowell.

Gentner, Dedre

2003 Why we're so smart. In Gentner, D. and S. Goldin-Meadow (eds.), Language in Mind. Advances in the Study of Language and Thought. Cambridge, MA: MIT, 195-235. 
Gentner, Dedre, B. F. Bowdle, P. Wolff, and C. Boronat

2001 Metaphor is like analogy. In Gentner, D., K. J. Holyoak and B. N. Kokinov (eds.), The Analogical Mind: Perspectives from Cognitive Science. Cambridge, MA: MIT Press, 199-253.

Gentner, Dedre, M. Imai, and L. Boroditsky

2002 As time goes by: Evidence for two systems in processing space $\Rightarrow$ time metaphors. Language and Cognitive Processes 17(5), 537-565.

Gibbs, Raymond W., and Markus Tendahl

2006 Cognitive effort and effects in metaphor comprehension: Relevance theory and psycholinguistics. Mind \& Language 21(3), 379-403.

Giora, R.

1999 On the priority of salient meanings: Studies of literal and figurative lan-

Glucksberg, Sam guage. Journal of Pragmatics 31: 919-929.

2001 Understanding Figurative Language: From Metaphors to Idioms. New York: Oxford University Press.

2003 The psycholinguistics of metaphor. Trends in Cognitive Sciences 7(2), 9296.

Goatly, Andrew Peter

1997 The Language of Metaphors. London: Routledge.

Goddard, Cliff

2004 The ethnopragmatics and semantics of 'active metaphors'. Journal of Pragmatics 36, 1211-1230.

Grady, Joseph

1999 A typology of motivation for conceptual metaphor. Correlation vs. Resemblance. In Gibbs, R. and G. Steen (eds.), Metaphor in Cognitive Linguistics. Amsterdam/Philadelphia: Benjamins, 79-100.

Grady, Joseph, and Christopher Johnson

2003 Converging evidence for the notions of subscene and primary scene. In Dirven, R. and R. Pörings (eds.), Metaphor and Metonymy in Comparison and Contrast. Berlin: Mouton de Gruyter, 533-554.

Hellsten, Iina

2000 Dolly: Scientific breakthrough or Frankenstein's monster? Journalistic and scientific metaphors of cloning. Metaphor and Symbol 15(4), 213-221.

Jackendoff, Ray, and David Aaron

1991 Review of G. Lakoff and M. Turner, 'More than cool reason: A field guide to poetic metaphor'. Language 67(2), 320-338.

Kintsch, Walter

$2001 \quad$ Predication. Cognitive Science 25, 173-202.

Lakoff, George

1993 The contemporary theory of metaphor. In Ortony, A. (ed.), Metaphor and

Thought. Cambridge: Cambridge University Press, 202-251.

Lakoff, George, and Mark Johnson

1980 Metaphors We Live By. Chicago: University of Chicago Press.

1999 Philosophy in the Flesh: The Embodied Mind and Its Challenge to Western

Thought. New York: Basic Books.

2003 Metaphors We Live By. 2nd ed. Chicago: University of Chicago Press.

McEnery, Tony, Yukio Tono, and Richard Zhonghua Xiao

2006 Corpus-Based Language Studies: An Advanced Resource Book. London:

Routledge. 
Murphy, Gregory

1996 On metaphoric representation. Cognition 60, 173-204.

Musolff, Andreas

2000 Political imagery of Europe: a house without exit doors? Journal of Multilingual and Multicultural Development 21(3), 216-229.

2004 Metaphor and Political Discourse. Analogical Reasoning in Debates about Europe. Basingstoke: Palgrave Macmillan.

2006 Metaphor scenarios in public discourse. Metaphor and Symbol 21(1), 23-38.

Nerlich, Brigitte

2006 The politics and ethics of metaphors: The case of Woo-Suk Hwang. Paper presented at The Researching and Applying Metaphor Conference, University of Leeds.

Rosch, E., C. Mervis, W. Gray, D. Johnson, and P. Boyes-Brae

1976 Basic objects in natural categories. Cognitive Psychology 8, 382-439.

Stern, Joseph

$2000 \quad$ Metaphor in Context. Cambridge, MA: MIT Press.

Talmy, Leonard

$2000 \quad$ Toward a Cognitive Semantics. Cambridge, MA: MIT Press.

Vervaeke, John, and John M. Kennedy

1995 Metaphors in language and thought: Falsification and multiple meanings.

Wierzbicka, Anna

1985 Lexicography and Conceptual Analysis. Ann Arbor, MI: Karoma Publishers.

Zinken, Jörg

2002 Imagination im Diskurs: Zur Modellierung metaphorischer Kommunikation und Kognition. Ph.D. dissertation, University of Bielefeld.

2003 Ideological imagination: Intertextual and correlational metaphors in political discourse. Discourse \& Society 14(4), 507-523.

Zinken, Jörg, Iina Hellsten, and Brigitte Nerlich

forthc. Discourse metaphors. In Dirven, R., R. Frank and E. Bernardez (eds.), Body, Language, and Mind: Sociocultural Situatedness. Berlin/New York: Mouton.

Zybatow, Lew

1995 Russisch im Wandel. Die russische Sprache seit der Perestrojka. Frankfurt: Peter Lang. 